\section{Professional Development and ESL Teacher Quality: An Empirical Study}

\author{
Abeywickrama, K.R.W.K. ${ }^{1, *}$ \\ ${ }^{1}$ Department of Languages, Sabaragamuwa University of Sri Lanka, Belihuloya, 70140, Sri Lanka.
}

Sri Lanka Journal of Social Sciences and Humanities Volume 1 Issue 2, August 2021: 51-58 ISSN: 2773 692X (Online), 27736911 (Print) Copyright: (C) 2021 The Author(s) Published by Faculty of Social Sciences and Languages, Sabaragamuwa University of Sri Lanka Website: https://www.sab.ac.lk/sljssh DOI: http://doi.org/10.4038/sljssh.v1i2.37

Received: 05 January, 2021, Revised: 12 March, 2021, Accepted: 19 April, 2021.

How to Cite this Article: Abeywickrama, K.R.W.K.H. (2021). Professional Development and ESL Teacher Quality: An Empirical Study. Sri Lanka Journal of Social Sciences and Humanities, 1(2), 51-58.

\begin{abstract}
A broader awareness of ESL teachers' conceptions for engaging in PD is vital for them to gain productive outcomes from prevail-ing Professional Development (PD) opportunities. The qualitative case study reported here investigated the implications of PD initiatives to heighten ESL teachers' quality in their professional practice. The study used semi-structured interviews to gather data from ten in-service ESL teachers of a government university in Sri Lanka and, Thematic Analysis for recognizing, arranging and interpreting data. The results demonstrated four key implications of PD that empowered teachers to enhance the quality in their practice: (a) refinement of teachers' character and behaviour (b) sustaining teachers' currency of knowledge in terms of qualifications, content and overall knowledge and experience, thereby growing into quality practitioners with certificates and credentials, (c) enriching teachers' quality of delivery via improved skills and expertise, and (d) maintaining teachers' profes-sional standards. These outcomes could be achieved through both independent and sponsored PD activities regulated by dem-ocratic and managerialist principles respectively. The study has valuable implications for PD providers and policy makers, and points to the need of considering them in designing, delivering and framing PD activities in ESL in order to achieve optimum learner outcomes via meaningful PD initiatives.
\end{abstract}

Keywords: democratic, managerialism, perceptions, professional development, quality

\section{INTRODUCTION}

Graduates with higher levels of English skills can mostly secure career opportunities in the Sri Lankan employment market, particularly, in the private sector, a graduate can earn higher salary than in the government sector (World Bank, 2009). However, it is important to note that many state university graduates cannot find a better employ-ment due to their inadequate English language proficiency (Perera \& Canagarajah, 2010; Ponnamperuma \& Nanayak-kara, 2018; Samrajya, 2008). Although ESL teachers' serv-ing in the Sri Lankan universities, major responsibility is to heightening students' English language proficiency, critical-ly, many teachers are unable to do so as they have inade-quate pedagogical content knowledge and language learn-ing methods (Abeywickrama, 2019; Liyanage, 2010; Navaz, 2012). As previous studies indicate, students' knowledge and skills can considerably be enriched through the provision of PD for teachers (Abeywickrama, 2020b; Abeywickrama \& Ariyaratne, 2020; Coldwell, 2017; Mohan, Lingam, \& Chand, 2017; Sixel, 2013; Villegas-Reimers, 2003). As such, institutions and policy designers are increasingly pressuring ESL practitioners to attend numerous PD activi-ties for enhancing their classroom practices. Although much research have examined the relationship between PD and student learning outcomes the areas such as the im-pact of teacher PD on teacher quality, and the importance of teacher quality for practitioners' growth and classroom teaching, have not yet been adequately researched. There-fore, the aim of this study is to explore ESL teachers' con-ceptions in order to recognize the significance of PD for their professional quality and thereby providing them more focused and meaningful PD opportunities for achieving the expected outcomes. This can finally enrich classroom prac-tices to benefit students and enhance their learning out-comes. Hence, the findings of this study are important for the development of "graduates' social and economic po-tential, and address the problem of the disadvantage of inadequate English language skills" (Abeywickrama, 2019, p.19).

\section{LITERATURE REVIEW}

\section{Theoretical framework}

The theory of constructivism has been widely applied to research in education that indicates the capability of constructivist principles for teachers' learning via PD (Abdal-Haqq, 1998; Cárdenas, González, \& Álvarez, 2010). Constructivism has broad connection with two theorists -psychological constructivism mainly linked with Jean Piaget (1896-1980), and social constructivism mostly associated with Lev Vygotsky (1896-1934). This research used psychological constructivism to indicate the capability of PD initiatives to produce new knowledge in association with teachers' existing knowledge. As Cannella and Reiff argue (1994), psychological constructivism, being a learning or "sense-making" the-

\footnotetext{
* Corresponding author: Tel.: +94 (71) 446 8577; Email: roh@ssl.sab.ac.lk
} (iD) https://orcid.org/0000-0002-0468-8186 
ory, demonstrates that the nature of knowledge and peoples' potential can change them into "empowered learners" (p. 28). This validates human beings' ability to develop new perceptions and knowledge in collaboration with their prior knowledge and understanding (Black \& Ammon, 1992; Cannella \& Reiff, 1994; Richardson, 1997).

Constructivism often promotes activities connecting to active engagement (Abdal-Haqq, 1998), inquiry, reflection (Cárdenas et al., 2010; Núñez Pardo \& Téllez Téllez, 2015) and communities of practice (Cornu \& Ewing, 2008). As these methods of PD mostly involve collaborative nature teachers have the opportunity to become professionals and adult learners (Abdal-Haqq, 1996), and gain broader awareness with higher internalization than less influential methods such as "an empiricist/reductionist approach" to PD (Abdal-Haqq, 1998, p. 1). In this sense, the theory of constructivism can be largely applied to research given the capability of constructivist principles for facilitating teacher learning and efficacy via PD activities (Abdal-Haqq, 1998; Cárdenas et al., 2010).

Teacher quality: Teacher quality is being increasingly discussed aspect in education reform forums and academic literature. Conversely, for Kennedy (2008) the term has become unclear as there are no sufficient acceptable explanations (see Chaves \& Guapacha, 2016; Novozhenina \& López Pinzón, 2018) accordingly, teacher quality refers to different constituents by writers: (a) tested ability, highest test scores for recruiting as teachers; (b) credentials, licenses, certificates and experience to demonstrate knowledge and skills; (c) class room practice, quality of practice/activities in the classroom; (d) skill in heightening students' performance; and (e) beliefs and values, nurturing positive attitudes and ability for understanding learner needs.

In contrast, the literature of language teaching considers qualifications, skills and experience, teaching learning strategies, and attitudes and beliefs the main aspects of teacher quality. More precisely, Chaves \& Guapacha (2016) categorize the constituents of teacher quality into four primary groups: "qualifications, knowledge, methodology, and image, [the last referring to] personal traits and professional attitudes, values, and beliefs" (p. 74). Besides, external factors such as learners' attitudes, time allocation for activities, availability and accessibility of resources, classroom size, and assessments and their conditions are also crucial in determining the quality of teachers (Hanushek \& Rivkin, 2007; Johnson, 2006; Wright, 2012). Surprisingly, researchers have not adequately investigated the implication and influence of these external determinants. As Tuinamuana (2011), argues, both observable and implicit values and standards are connected to teacher quality thus, for Kennedy (2008), teacher quality cannot be effectively assessed especially in situations where all these constituents concurrently affect teachers' classroom practices:

True understanding of teacher quality requires us to recognize that these many facets are distinct, not always overlapping, and not always related to one another. Moreover, we are not even sure how they influence and interact with one another when they do. (p. 60)

Irrespective of these complications, all investigators strongly acknowledge that the key objectives of maintaining teacher quality are to heighten learners' performance (AL-Qahtani, 2015; Bandara, 2018; Bellibas, Gumus, \& Boylan, 2016; Girvan, Conneely, \& Tangney, 2016; Marchand \& Weber, 2015) and enrich practitioners' identity and standards (Liyanage, Walker, \& Singh, 2015). In this context, teachers should use their subject knowledge and competence for planning, delivery and evaluation of creative and innovative teaching and learning, and are responsible for effectively integrating all elements of quality teaching to obtain higher results by optimizing learner engagement (National Council for Teacher Education, 2012). The investigations that explored teacher quality and its impacts on learner outcomes have affirmed that teacher PD has a significant connection with teacher quality (AL-Qahtani, 2015; Mahmoudi \& Özkan, 2015) and ongoing learning (Edge, Reynolds, O'Toole, \& Boylan, 2015). Given that, various institutions and professional bodies are now broadly investing in teacher PD initiatives to provide opportunities for teachers' to enrich their learning thereby improving quality of their classroom practices (Gore et al., 2017). As Chaves and Guapacha (2016) believe, such PD activities are vital to establish quality education in a country, and if this the case, provision of systematic PD for ESL teachers is essential to cater for the quality issue in the Sri Lankan university sector.

The evidence in the literature validates that teacher professionalism and professionalization are strongly connected to teacher quality. As conceptualized by Englund (1996), professionalism in education refers to teachers' mandatory duties and responsibilities in which they demonstrate their internal quality of teaching. On the contrary, professionalization is the historical and sociological practice (Englund, 1996) which has a significant association with administration and status of the teaching profession (Buyruk, 2014). Investigating diverse definitions of professionalism in the literature, Evans (2008) claims that professionalism works as an agreement between the organization and employee which includes the terms and conditions of the employment. Furthermore, Evans claims,

Many interpretations seem to focus on professionalism as being an externally imposed, articulated perception of what lies within the parameters of a profession's collective remit and responsibilities. In setting the positions of these parameters - and, hence, in defining the boundaries of the profession's actual and potential authority, power and influence - external agencies appear to have the capacity for designing and delineating professions. (p. 4)

However, as Breshears (2004), underscores, the general public is the most powerful agency that can determine the degree of professionalization and professionalism of an occupational group in considering the development of their work conditions. On the other hand, it is also claimed that "professional culture makes up a large proportion of what, in many cases, is considered to be professionalism" (Evans, 2008, p. 6).

Even though the new democratic approach of professionalization appears in a manner in which teachers can safeguard their rights and dignity, this is not always the case. For, Whitty (2000) and other critics of education reform, the integrated regulations have caused to grow a trend towards "de-professionalization" of teachers (p. 282). Conversely, advocates of the education reform claim that the new development is a "one of re-professionalization, making teacher professionalism more in keeping with the needs of a new era" (Whitty, 2000, p. 282), whereas recent investigations suggest two strong dimensions that can advance de-professionalization. First, there are less opportunities to accommodate teachers' autonomy and agency in the workplace context, (Biesta, Priestley, \& Robinson, 2015), and second, teachers' importance in the employment market is gradually diminishing due to progressive availability of knowledge for 
learners across time and space with the new technological development (Buyruk, 2014). These arguments strongly contribute to the discussion of teacher professionalism and professionalization in the twenty-first century. As discussed previously, teacher professionalism can broadly contribute to teacher quality thus, learners can enrich their performance and learning outcomes, this means that these concepts have much importance to the ESL practitioners at the Sri Lankan university sector.

Independent and sponsored professional development: Teachers usually enhance their knowledge, skills and expertise through independent and sponsored professional development activities (Abeywickrama, 2019, 2020b). Managerialism often regulates sponsored PD, sets "professional standards and frames the content and aims" of the activities (Evans \& Esch, 2013, p. 137). As Day and Sachs (2004) claim, Managerialist principles always focuses on corporate goals and standardized criteria which often evaluate teachers and students' contribution to institutional responsibility. On the contrary, independent PD driven by democratic professionalism is broadly connected to practitioner-centred initiatives and focusses on teachers' democratic goals, principles and needs (Abeywickrama, 2019, 2020a). The primary aim of democratic professionalism is to encourage collaborative teaching and learning among all stake holders in the industry and ensure that practitioners are responsible for the entire education system (Sachs, 2001) and larger community (Day \& Sachs, 2004) not only to the students whom they teach (Sachs, 2001). Managerialism, on the other hand, prioritizes industrial values and requirements (Bolam, 2000; Deem \& Brehony, 2005; Skinner, Leavey, \& Rothi, 2019) rather than affirming teachers' professional identities (Bloomfield, 2006; Skinner et al., 2019). Conversely, as Sachs (2001) argues, managerialism can also contribute to heighten treachers' professional identity.

Researchers have no agreement regarding the way PD should be designed and offered to practitioners (Tan, Chang, \& Teng, 2015). As Fischer (2000) argues, engaging in PD activities without institutional mandate can provide meaningful learning opportunities for practitioners thus, enable them to be lifelong learners. While others believe that the knowledge and skills gained via independent PD are not always adequate to introduce necessary changes to the classroom teaching (Morgan, 2010). This means that the institutional involvement in teacher PD cannot be disregarded due to the support of institutions to design effective teacher PD programs (Bozat, Bozat, \& Hursen, 2013; Gurney, Liyanage, \& Gharachorloo, 2014). Although there is "overlapping, inseparable and sometimes uneasy" (Gurney \& Liyanage, 2016, p. 1) relationship between the two types of PD: sponsored and independent, teachers' personal goals and their preparedness for heightening their professional practice mostly determine whether they engage in PD activities.

\section{MATERIALS AND METHODS}

The case study approach was used in this qualitative investigation in order to retain quality, relevance and impact (Chapelle \& Duff, 2003; Patton, 2002). Rather than examining the phenomena as units, this approach enabled to analyze the case broadly (Ary, Jacobs, Sorensen, \& Warker, 2014), and "holistically" (Patton, 2002, p. 55), in participants' actual context allowing the researcher to identify the phenomena more effectively based on their perceptions (Gajadeera, 2006; Denzin \& Lincoln as cited in Savenye \& Robinson, 2005; Zadrozny, Mcclure, Lee, \& Jo, 2016).
Participants, context and instrument: The study consisted of ten ESL practitioners working on a full-time basis in the [name of the department] of a government university in Sri Lanka and they were selected purposefully for making thorough analysis of information-rich cases. Minimum qualifications or experience were not set for respondents to participate in the study, however, all have post-graduate qualifications. The selected group which included seven males and three females contained both novice as well as experienced ESL practitioners. Semi-structured interviews were used as the method of data collection and each respondent was interviewed for 40-60 minutes duration. This instrument has more flexibility and depth than other data collection methods (Burns, 2000; Cohen \& Manion, 1994; Hitchcock \& Hughes, 1995; Zacharias, 2012). Therefore, the investigator could carry out the interviews in a way he gained unexpected results, encouraged respondents for more detailed responses and obtained justifications for such replies (Ashworth \& Lucas, 2000; Cohen \& Manion, 1994).

Thematic Analysis: Braun and Clarke's (2006) inductive approach of Thematic Analysis (TA) was utilized as the tool in order to recognize, analyze and interpret the data. Many researchers over the last decade have used TA in research in education (Coldwell, 2017; Crowe, Inder, \& Porter, 2015; Liyanage \& Bartlett, 2010; Skinner et al., 2019; Tuckett, 2005). The six stages in TA: (a) familiarizing with data; (b) generating initial codes; (c) searching for themes; (d) reviewing themes; (e) defining and naming themes; and (f) producing the report (see Braun \& Clarke, 2006), largely helped identify and expose the significance of PD activities to heighten teacher quality and their personal and professional growth.

At the first step of TA, the researcher familiarized and internalized data by thoroughly reading the transcribed interviews. To facilitate this process, each interview transcription was imported into NVivo qualitative data analysis software thus, the researcher could recognize meaning and diverse patterns by immersing in data. At the second stage, the researcher identified the chunks of texts in the interview transcriptions which had connections with the research questions and categorized them with a code. Here, the researcher categorized the identified fragments of texts in the individual transcriptions for as many possible patterns. This was followed by extracting the fragmented statements from each transcription and arranged them together within each code. The fragmented statements within each data set were labelled through NVivo's coding process. This stage is an important part of TA (Tuckett, 2005) as the initial theoretical content is identified in this practice (Braun \& Clarke, 2006).

In the third step, the codes created in the second stage were clustered into conceptions based on their connections. Then, the extracted important themes were arranged together as the emerging themes (Liyanage \& Bartlett, 2010). For Braun and Clarke (2006), a theme always represents the main idea of data set collected in relation to research questions, and indicates some kind of pattern or importance. In this process, the researcher ensured that he extracted all data connecting to individual themes from the interview transcriptions, and they had a connection with the specific codes and also with the themes (Crowe et al., 2015). This raw data refinement process broadly supported the researcher to obtain higher level of understanding.

In the next step, the researcher further refined and reviewed the developed themes. To this end, the researcher thoroughly scrutinized all categorized extracts which had as- 
sociation with the themes, and ensured that they demonstrated a logical pattern and adequately signified the "contours data" (Braun \& Clarke, 2006, p. 26). Then, individual themes were validated concerning the overall data set to ensure that views represented in data were accurately indicated. In the fifth stage, the researcher compared each developed theme across all themes and recognized the scope and implication of them for teacher quality (see Figure 1). At this stage, the themes developed by a systematic handling of the data following the TA changed into groups for presentation (Yukhymenko, Brown, Lawless, Brodowinska, \& Mullin, 2014). The last step of TA, writing of the report, commenced after fully finalizing all themes. The next section of the of the article will provide sufficient evidence for each theme of teacher quality within the data followed by the quotations relevant to the conceptions reported, so as to retain the value of the findings.

\section{RESULTS AND DISCUSSION}

Findings of the study illustrate that heightening teacher quality is one of the key motives for participating in PD activities. Participants believed that they should develop some standards and acquire certain credentials in order to be considered quality resourceful ESL practitioners. Despite what subject is being taught, these values are important to all teachers in the higher education institutions in order to be quality practitioners and develop quality education in their classrooms. As demonstrated in the figure given below, participants exposed four perceptions of teacher quality that can be achieved through PD initiatives.

\section{Figure 01- Perceptions of teacher quality}

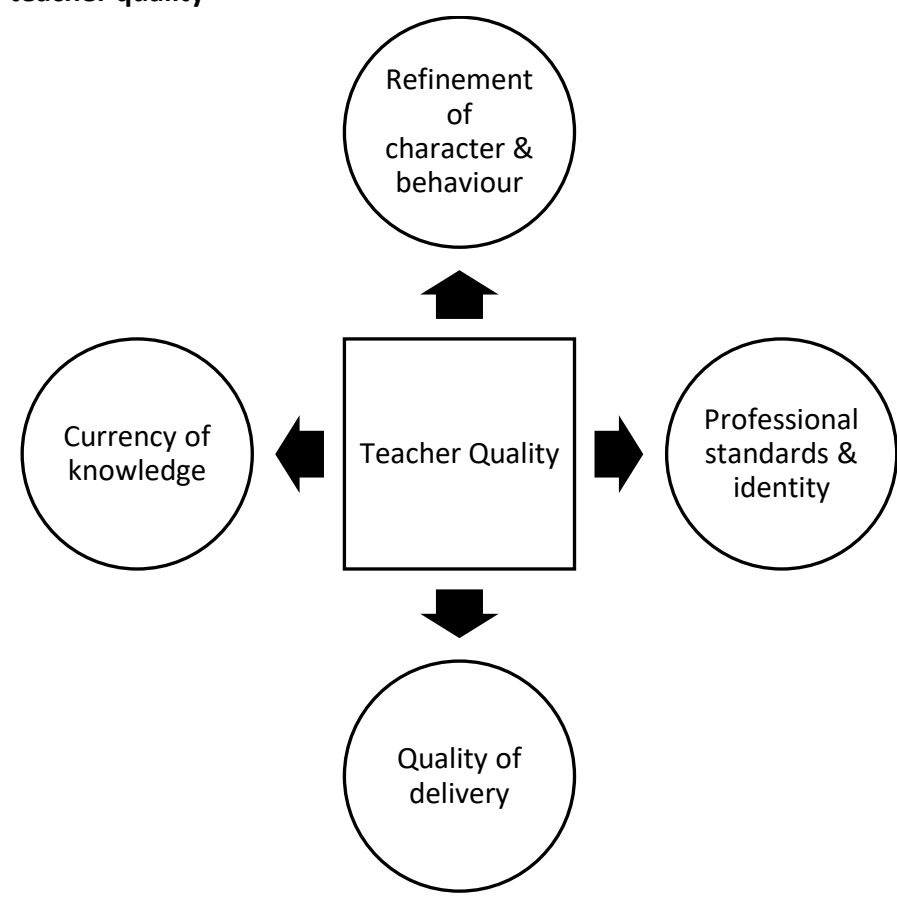

One perception situated teachers' character and behaviour refinement as a key outcome of PD that empowered teachers to enrich the quality in their profession. More specifically, focussed PD activities can re-orient teachers' professional practice so as to address their learner needs and individual differences, a path encouraged in education to sustain quality of teachers' classroom practices. These views, for instance, were broadly reflected in the case of Participant 3.

If a teacher can properly understand the needs of students, their background and their learning capacities then the teacher can provide proper teaching. Not only psychology, even the teacher can find out the socio-economic level of the students and understand them. In addition, a language teacher's duty is to recognize their language needs and what they need to do in the future. These kinds of things also have a connection with teacher quality. (Lines 166-171)

Especially, this extract demonstrates how the perceived correlation between teacher quality, wider social/economical relationships, and classroom teaching connect to learners' personal and career development. Participant 5 also reported a similar relationship between PD and teachers' behavioural transformation. She commented,
I think PD goes along with some ethics. Being a language teacher, we need to have many good qualities in us personally, and then if we can improve them through PD they will be so effective. That's what I think. Because we need to be very humble, and you know we need to have a lot of patience and endurance when we handle a language classroom. (Lines 193-196)

In particular, being considerate and empathetic with learners' personal circumstances, and being aware of their individual differences are essential to build a better understanding with them. As Lasky (2005) claims, this is a significant aspect of teacher professional capital that can be invested in classroom practices in support of a more productive environment for learning.

\section{Sustaining currency of knowledge}

Participants also placed sustaining currency of knowledge in relation to qualifications, content and overall knowledge and experience as a major outcome of PD. Participants can enrich their quality in pursuit of these constituents thus, they may support to create an effective workplace context. Participant 7, for instance, exposed, "if a teacher can gather more experiences and also overall knowledge that is the quality of teaching" (Lines 131-132). This means that, "when there are quality professionals or quality teachers there is a 
high possibility for students to get benefited" (Participant 1, Lines 275 -276). Critically, teachers' lack of qualifications, content and overall knowledge can negatively influence their classroom practices, and subsequently, students learning outcomes. This perception was clearly reflected in the comments of Participant 2:

Learners have to be given exposure in terms of subject matter and language, if we don't have the richness in our language and in our subject matter, the students would lose confidence in us. If we are rich, ah... yes. And then, when the students listen to us confidently placing a lot of confidence in us, ah...things get integrated in their brains better. Otherwise, we will lose. (Lines 148-152)

\section{Heightening quality of delivery}

In addition, participants highly emphasized the importance of PD in enhancing teachers' quality of delivery via improved skills and expertise. As Participant 4 revealed, "how far he/she [a teacher] is able to uh...do this [delivery] effectively is a kind of professional quality" (Lines 173-174). As observed by participants, students used to identify this quality in comparison with the delivery of another practitioner who demonstrates high standard teaching practice and a commitment to learner-centred teaching. If this is the case, recruiting "professionally qualified" practitioners (Participant 8 , Line 319) and ensuring their quality through PD activities are essential to heighten their professional practice, enrich their self-image and develop their interest to retain in the system.

\section{Professional standards and identity}

The final perception indicated the significance of PD activities for maintaining participants' professional standards which is also a way to demonstrate the quality in their practice. As participants reflected, teachers' professional standards and norms function as motives that can encourage students' attendance to their classes. For Participant 6, learners involuntarily use their prior experience to set benchmarks to evaluate their teachers' values and standards:

Teachers need to be exemplary for students, standards for the students to reach. If teachers are very poor in standards, I mean the teachers cannot guide the students to a certain level. How can we advise students to reach to a certain level if teachers are not at that level? (Participant 6, Lines 180-183)

As Participant 4 reported, professional standards largely supported practitioners to maintain their distinctiveness. For him, "in fact, it is very difficult to survive in an academic environment and even the students may not accept us. Then our professional career may go down" (Lines180 -181). This means that, a teacher's identity may be determined by the activity or the context in which he or she is situated. In general, this perception of PD enables teachers to sustain their professional standards and identity within and beyond their workplace context, thus functions as a trajectory for their quality enhancement.

As claimed by Ivanova and Skara-MincL-ne (2016), teachers who have strong and positive professional identity always engage in independent learning that helps them acquire knowledge and skills needed for their ongoing practice. This is vital for practitioners for institutionalizing their standards and identity. On the other hand, formal teacher standards frameworks that operate as motives for teachers' quality enhancement always encourage teachers' PD (Fransson, Gallant, \& Shanks, 2018). Most importantly, Sri Lankan univer- sities have planned to achieve ESL practitioners' professional standards, which were implemented under the Manual for Review of Undergraduate Study Programs 2015, through PD initiatives.

\section{Teacher quality, managerialism and democratic professionalism}

In examining the findings carefully, it is noted that participants' perceptions of teacher quality were not specifically connected to either independent or sponsored PD activities. This is mainly because for both managerialist and democratic professionalism, teachers' quality enhancement is a means for improved classroom practice. As such, teachers were motivated to engage in PD activities for enriching the quality in their practice despite the type of PD: independent or sponsored. However, the extent to which participants engage in self-directed learning or institutionally-facilitated PD activities was mostly dependent on the relevance and usefulness of the activity to achieve their goals. But, for refinement of character and behaviour participants mostly used sponsored PD activities driven by managerialism. This is because institutional intervention is required to effectively achieve this outcome.

\section{$P D$, lifelong learning and teacher quality}

The findings also reveal the strong connection between PD, teacher quality and lifelong learning. According to this relationship, in-service PD is vital for instilling lifelong learning that can lead to enhanced teacher quality and better classroom practices as in the case of Participant 6:

When we learn throughout life we gather experience. We know what to remove and what to keep what to improve, and we understand all those things very well. So, I personally feel that lifelong learning plays a big role in maintaining teacher quality and classroom teaching (Lines 195197)

It is important to note that all practitioners, both novice and experienced need to participate in ongoing PD as a way for lifelong learning and continuously explore new methods to enhance their quality and professional standards, and also identify strategies to instil lifelong learning interest in their learners. Especially, participants' view that they can construct quality in their practice with the experience they acquire through PD activities has a significant connection with the Sri Lanka Qualification Framework (SLQF) which has identified heightening teacher quality and lifelong learning as the two main aspects for quality assurance of the Sri Lankan university sector (SLQF, 2015). This means that educational policies and reforms need to include measures and strategies that enrich teachers' lifelong learning, thus they may develop self-reliance to engage in independent learning on their own or collaborative practices with their peers for achieving their developmental goals (Villegas-Reimers, 2003).

\section{Implication of computer-mediated communication technologies for teacher quality}

It is also important to note that teachers broadly sought the support of digital internet-assisted tools and applications, and social media platforms to enhance their quality. Especially, participants use the internet-assisted applications for upgrading their content and overall knowledge. Participant 1 , for instance, emphasized, "I have various applications in my phone which help me gain knowledge. I have the applications which were specifically built to improve the knowledge in terms of phonetics and semantics" (Lines 166- 
167). Participants' perceptions also demonstrated that practitioners could fulfil their intrinsic motivation for self-regulated learning with the support of the internet-assisted tools and software. The significance of social media for improved teaching practice and developing connections and collaboration with other practitioners was effectively reflected on the comments of Participant 8:

I am on Facebook I had like a host or pages related to my field and I think it is a good way to be connected with professionals in the same field. Through that, I learnt many innovative methods, ideas and I gained many activities to incorporate into the real classroom. (Participant 8, Lines 136-139)

Especially, these views demonstrates teachers' strong concern to take individual responsibility for their PD "as free agent learners" (Mushayikwa \& Lubben, 2009, p. 376), and social networks' contribution for accessing materials, resources and support (Alberth, Mursalim, Siam, Suardika, \& Ino, 2018) across time and space (Parsons et al., 2019). Prior research also suggests that social media platform is an effective shared learning space where teachers produce new knowledge and negotiate their individual classroom practices (Dabbagh \& Kitsantas, 2012; Doak, 2018; Haworth, 2016; Morgan, 2010; Visser, Evering, \& Barrett, 2014). Although the increased support of network technologies for independent learning is well documented in the literature whether ESL teachers' have sufficient self-regulatory skills to manage such tools and applications to enrich their standards and quality in practice is a question. Thus, provision of "personal knowledge management skills" (Dabbagh \& Kitsantas, 2012, p. 7) by institutions will support practitioners to gain necessary knowledge to customize and sustain such tools, and thereby maximizing the outcome of self-directed learning.

Overall, participants' perceptions of teacher quality have a strong alliance with the dominant definitions in the literature. Although PD initiatives broadly support teachers' quality enhancement its actual impact is highly unlikely to be measured as various other external and work-related aspects can also take effect simultaneously (see Hanushek \& Rivkin, 2007; Johnson, 2006; Wright, 2012). Teachers' perceptions also demonstrated their understanding of the need to sustain the quality in standards of professionalism and professionalization for which the external agencies generally set parameters. Notably, it is essential to promote teachers' interest for pursuing PD to enhance their quality in practice, and on the other hand, available opportunities must also cater for practitioner needs to facilitate their perceptions to establish quality teaching in higher education.

\section{CONCLUSIONS}

Findings of the study expose that improving teacher quality is one of the primary goals for engaging in PD initiatives. Participants elaborated four aspects of teacher quality; (a) refining teachers' character and behaviour in a manner they enhance the quality in their classroom practice (b) sustaining currency of knowledge in relation to qualifications, content and overall knowledge and experience, (c) developing teacher's quality of delivery through improved expertise and skills, and (d) enriching professional standards and identity. These components are not only significance to ESL practitioners and industry but also largely beneficial to all teachers in education for sustaining their persona and ensuring quality in their practice. Findings also demonstrate that although there are considerable differences between independent and sponsored PD in relation to the goals and learning outcomes both types can provide meaningful learning opportunities to heighten teacher quality.

\section{Implications, limitations and recommendations for future research}

Enhancing the quality of ESL teachers in the Sri Lankan university sector through the provision of PD is vital for them to improve their students' English language skills. Being aware of participants' perceptions of the constituents of teacher quality would have been useful to address their needs via more focused and productive PD opportunities. Hence, findings of the study are valuable for PD providers, policy designers and institutions with regard to framing and delivery of PD programs in ESL. Findings are also of beneficial to professional establishment of ESL teachers in the Sri Lankan tertiary sector and any other similar educational or organizational contexts as well as to improve their orientations.

Although the number of participants involved in this investigation is similar to the previous studies of this nature if the sample had comprised more participants and representatives from several universities in Sri Lanka and in other contexts findings would have been more generalized. Although the research reported important findings for policy designers, facilitators of PD, and institutions in relation to the design and delivery of PD activities for ESL teachers the study had not examined the perceptions of at least one of these stakeholders, thus it is somewhat challenging to gain more holistic view of the entire phenomenon. Future studies should investigate the perceptions of PD providers, policy designers and institutions in Sri Lanka and other similar contexts in order to recognize the intersection between PD and teacher quality. Such studies can consider to which extent the two types of PD: independent and sponsored activities could support to heighten teacher quality. The results of such studies would provide a better understanding of the phenomenon and contribute to the discussion of what constitutes teacher quality.

\section{REFERENCES}

Abdal-Haqq, I. (1996). Making time for teacher professional development. ERIC Digest. Retrieved from http://files.eric.ed.gov/fulltext/ED400259.pdf

Abdal-Haqq, I. (1998). Constructivism in teacher education: Considerations for those who would link practice to theory. ERIC Digest. Retrieved from https://files.eric.ed.gov/fulltext

Abeywickrama, K. R. W. K. H. (2019). Teacher engagement and professional development initiatives: A case study of university ESL teachers in Sri Lanka. Unpublished PhD. Deakin University. Australia

Abeywickrama, K. R. W. K. H. (2020a). ESL teachers' perceptions and design and delivery of Professional Development. American Journal of Humanities and Social Sciences Research, 4(8), 426-434.

Abeywickrama, K. R. W. K. H. (2020b). Professional development and ESL teachers' career enhancement. International Journal of Research and Innovation in Social Science (IJRISS), 4(9), 495-503.

Abeywickrama, K. R. W. K. H., \& Ariyaratne, W. M. (2020). Professional Development (PD) for ESL teachers' knowledge orientation: An empirical study. American Journal of Humanities and Social Sciences Research, 4(5), 107-119.

AL-Qahtani, H. M. (2015). Teachers' voice: A needs analysis of teachers' needs for professional development with the emergence of the current English textbooks. English Language Teaching, 8(8), 128-141. doi:10.5539/elt.v6n8p128

Alberth, A., Mursalim, M., Siam, S., Suardika, I. K., \& Ino, L. (2018). Social media as a conduit for teacher professional development in the digital era: Myths, promises or realities? TEFLIN Journal, 29(2), 293-306. doi:10.15639/teflinjournal.v29i2/293-306 
Ary, D., Jacobs, L. H., Sorensen, C., \& Warker, A. D. (2014). Introduction to research in education: Research approaches in education ( $9^{\text {th }}$ ed.) CA: Wadsworth.

Ashworth, P., \& Lucas, U. (2000). Achieving empathy and engagement: A practical approach to the design, conduct and reporting of phenomenographic research. Studies in Higher Education, 25(3), 295-308.

Bandara, S. (2018). School-based teacher development programs in secondary schools in Sri Lanka. International Journal of Research-GRANTHAALAYAH, 6(5), 190-200. doi:10.5281/zenodo.1269759

Bellibas, M. S., Gumus, E., \& Boylan, M. (2016). Teachers' perceptions of the quantity and quality of professional development activities in Turkey. Cogent Education, 3(1), 1-15. doi:10.1080/2331186x.2016.1172950

Biesta, G., Priestley, M., \& Robinson, S. (2015). The role of beliefs in teacher agency. Teachers and Teaching: Theory and Practice, 21(6), 624-640. doi:10.1080/13540602.2015.1044325

Black, A., \& Ammon, P. (1992). A developmental-constructivist approach to teacher education. Journal of Teacher Education, 43(5), 323-335.

Bloomfield, D. (2006). A new discourse for teacher professionalism: Ramsey, standards and accountability. Paper presented at the Australian Association for Research in Education, Adelaide, Australia.

Bolam, R. (2000). Emerging policy trends: Some implications for continuing professional development. Journal of In-Service Education, 26(2), 267-280. doi:10.1080/13674580000200113

Bozat, P. B., Bozat, N., \& Hursen, C. (2013). The evaluation of competence perceptions of primary school teachers for the lifelong learning approach. Procedia: Social and Behavioral Sciences, 140, 476-482. doi:10.1016/j.sbspro.2014.04.456

Braun, V., \& Clarke, V. (2006). Using thematic analysis in psychology. Qualitative Research in Psychology, 3(2), 77-101. doi:10.1191/1478088706qp063oa

Breshears, S. (2004). Professionalization and exclusion. TESL Canada Journal, Special Vol(4), 23-38.

Burns, R. B. (2000). Introduction to research methods (4th ed.). Frenchs Forest: Longman.

Buyruk, H. (2014). "Professionalization" or "Proletarianization": Which concept defines the changes in teachers' work? Procedia: Social and Behavioral Sciences, 116, 1709-1714. doi:10.1016/j.sbspro.2014.01.460

Cannella, G. S., \& Reiff, J. C. (1994). Individual constructivist teacher education: Teachers as empowered learners. Teacher Education Quarterly, 21(3), 27-38.

Cárdenas, M., González, A., \& Álvarez, J. (2010). El desarrollo profesional de los docents de inglés en ejercicio: Algunas consideraciones conceptuales para Colombia [In-service English language teachers' professional development: Some conceptual considerations for Colombia]. Folios, 31, 49-67.

Chapelle, C. A., \& Duff, P. A. (2003). Some guidelines for conducting quantitative and qualitative research in TESOL. TESOL Quarterly, 37(1), 157-178.

Chaves, O., \& Guapacha, M. E. (2016). An eclectic professional development proposal for English language teachers. PROFILE: Issues in Teachers' Professional Development, 18(1), 71-96. doi:10.15446/profile.v18n1.49946

Cohen, L., \& Manion, L. (1994). Research methods in education (4th ed.) London: Routledge.

Coldwell, M. (2017). Exploring the influence of professional development on teacher careers: A path model approach. Teaching and Teacher Education: An International Journal of Research and Studies, 61, 189-198. doi:10.1016/j.tate.2016.10.015

Cornu, R. L., \& Ewing, R. (2008). Reconceptualising professional experiences in pre-service teacher education...reconstructing the past to embrace the future. Teaching and Teacher Education: An International Journal of Research and Studies, 24, 1799-1812. doi:10.1016/j.tate.2008.02.008

Crowe, M., Inder, M., \& Porter, R. (2015). Conducting qualitative research in mental health: Thematic and content analyses. Aust $N Z$ Psychiatry, 49(7), 616-623. doi:10.1177/0004867415582053

Dabbagh, N., \& Kitsantas, A. (2012). Personal Learning Environments, social media, and self-regulated learning: A natural formula for connecting formal and informal learning. The Internet and Higher Education, 15(1), 3-8. doi:10.1016/j.iheduc.2011.06.002
Day, C., \& Sachs, J. (2004). professionalism, performativity and empowerment: Discourses in the politics, policies and purposes of continuing professional development. In C. Day \& J. Sachs (Eds.), International handbook on the continuing professional development of teachers (pp. 3-32). Berkshire, England: Open University Press.

Deem, R., \& Brehony, K. J. (2005). Management as ideology: The case of 'new managerialism' in higher education. Oxford Review of Education, 31(2), 217-235. doi:10.1080/03054980500117827

Doak, S. H. (2018). Social media as a personal learning network for professional development: Teachers in international schools use and perspectives. Unpublished PhD. Boise State University. Idaho, USA

Edge, K., Reynolds, R., O’Toole, M., \& Boylan, M. (2015). Contextual complexity: The professional learning experiences of seven classroom teachers when engaged in "quality teaching". Cogent Education, 2(1), 1-15. doi:10.1080/2331186x.2015.1120002

Englund, T. (1996). Are professional teachers a good thing? In I. F. Goodson \& A. Hargreaves (Eds.), Teachers' professional lives (pp. 75-87). London: Falmer Press.

Evans, L. (2008). Professionalism, professionality and the development of education professionals. British Journal of Educational Studies, 56(1), 20-38.

Evans, L., \& Esch, E. (2013). The elusive boundaries of second language teacher professional development. The Language Learning Journal, 41(2), 137-141. doi:10.1080/09571736.2013.790129

Fischer, G. (2000). Lifelong learning: More than training. Journal of Interactive Learning. Research, 11(3), 265-294.

Fransson, G., Gallant, A., \& Shanks, R. (2018). Human elements and the pragmatic approach in the Australian, Scottish and Swedish standards for newly qualified teachers. Journal of Educational Change, 19(2), 243-267. doi:10.1007/s10833-018-9321-8

Gajadeera, S. R. (2006). An exploration of the challenges of sustainable and effective professional development for English as second language teachers in Sri Lanka. Unpublished PhD. University of Wollongong. Australia.

Girvan, C., Conneely, C., \& Tangney, B. (2016). Extending experiential learning in teacher professional development. Teaching and Teacher Education: An International Journal of Research and Studies, 58, 129139.

Gore, J., Lloyd, A., Smith, M., Bowe, J., Ellis, H., \& Lubans, D. (2017). Effects of professional development on the quality of teaching: Results from a randomised controlled trial of Quality Teaching Rounds. Teaching and Teacher Education: An International Journal of Research and Studies, 68, 99-113. doi:10.1016/j.tate.2017.08.007

Gurney, L., \& Liyanage, I. (2016). EAL teacher agency: Implications for participation in professional development. International Journal of Pedagogies and Learning, 11(1), 49-59. doi:10.1080/22040552.2016.1187650

Gurney, L., Liyanage, I., \& Gharachorloo, H. (2014). EAL teachers' identity and agency: The impact of participant positioning through in-service professional development. Paper presented at the Vaka Pasifiki Education Conference, Tongatapu, Kingdom of Tonga.

Hanushek, E. A., \& Rivkin, S. G. (2007). Pay, working conditions, and teacher quality. Future Child, 17(1), 69-86.

Haworth, R. (2016). Personal learning environments: A solution for selfdirected learners. TechTrends, 60(4), 359-364. doi:10.1007/s11528016-0074-z

Hitchcock, G., \& Hughes, D. (1995). Research and the teacher: A qualitative introduction to school based research (2nd ed.). London: Routledge.

Ivanova, I., \& Skara-MincL'ne, R. (2016). Development of professional identity during teacher's practice. Procedia: Social and Behavioral Sciences, 232, 529-536. doi:10.1016/j.sbspro.2016.10.073

Johnson, S. M. (2006). The work place matters: Teacher quality, retention, and effectiveness. Washington, DC: National Education Association.

Kennedy, M. M. (2008). Sorting out teacher quality. Phi Delta Kappan, 90(1), 59-63.

Lasky, S. (2005). A sociocultural approach to understanding teacher identity, agency and professional vulnerability in a context of secondary school reform. Teaching and Teacher Education: An International Journal of Research and Studies, 21(8), 899-916. doi:10.1016/j.tate.2005.06.003 
Liyanage, I. (2010). Globalization: Medium-of-Instruction Policy, indigeneous educational systems and ELT in Sri Lanka. In V. Vaish (Ed.) Globalization of language and culture in Asia (pp. 206-230). London: Continuum Press.

Liyanage, I., \& Bartlett, B. J. (2010). From autopsy to biopsy: A metacognitive view of lesson planning and teacher trainees in ELT. Teaching and Teacher Education: An International Journal of Research and Studies, 26(7), 1362-1371. doi:10.1016/j.tate.2010.03.006

Liyanage, I., Walker, T., \& Singh, P. (2015). TESOL professional standards in the "Asian century": Dilemmas facing Australian TESOL teacher education. Asia Pacific Journal of Education, 35(4), 485-497. doi:10.1080/02188791.2013.876388

Mahmoudi, F., \& Özkan, Y. (2015). Exploring experienced and novice teachers' perceptions about professional development activities. Procedia: Social and Behavioral Sciences, 199, 57-64. doi:10.1016/j.sbspro.2015.07.487

Marchand, J., \& Weber, J. G. (2015). The labor market and school finance effects of the Texas shale boom on teacher quality and student achievement. Working Paper No.15. Retrieved from https://sites.ualberta.ca/ econwps/2015/wp2015-15.pdf

Mohan, P., Lingam, G., \& Chand, D. (2017). Teachers' perceptions of the impact of professional development on learning and teaching in a developing nation. Australian Journal of Teacher Education, 42(11), 18 33. doi:10.14221/ajte.2017v42n11.2

Morgan, D. T. H. (2010). The impact of job-embedded professional development coaches on teacher practice. Unpublished PhD. East Tennessee State University. USA.

Mushayikwa, E., \& Lubben, F. (2009). Self-directed professional development: Hope for teachers working in deprived environments? Teaching and Teacher Education: An International Journal of Research and Studies, 25(3), 375-382. doi:10.1016/j.tate.2008.12.003

National Council for Teacher Education. (2012). Developing an NCTE position on teacher quality. Retrieved from http://www.ncte.org/magazine/archives/118521

Navaz, A. M. M. (2012). Lecturer-student interaction in English-medium science lectures: An investigation of perceptions and practice at a Sri Lankan university where English is a second language. Unpublished PhD. University of Nottingham. UK.

Novozhenina, A., \& López Pinzón, M. M. (2018). Impact of a professional development program on EFL teachers' performance. HOW, 25(2), 113-128. doi:10.19183/how.25.2.406

Núñez Pardo, A., \& Téllez Téllez, M. F. (2015). Reflection on teachers' personal and professional growth through a materials development seminar. HOW, 22(2), 54-74.

Parsons, S. A., Hutchison, A. C., Hall, L. A., Parsons, A. W., Ives, S. T., \& Leggett, A. B. (2019). U.S. teachers' perceptions of online professional development. Teaching and Teacher Education: An Internationa Journal of Research and Studies, 82, 33-42. doi:10.1016/j.tate.2019.03.006

Patton, M. Q. (2002). Qualitative research \& evaluation methods (3rd ed.). Thousand Oaks, CA: SAGE.

Perera, K., \& Canagarajah, S. (2010). Teaching in Sri Lanka: Foreign resources and local responses. In V. Vaish (Ed.), Globalization of language and culture in Asia (pp. 106-119). London: Continuum Press.

Ponnamperuma, G., \& Nanayakkara, V. (2018). Sri Lanka: Revitalizing higher education to develop twenty-first century graduates. In $\mathrm{H}$. Letchamanan \& D. Dhar (Eds.), Education in South Asia and the Indian Ocean islands (pp. 225-243). London: Bloomsbury.

Richardson, V. (1997). Constructivist teaching and teacher education: Theory and practice. In V. Richardson (Ed.), Constructivist teacher ed ucation: Building new understandings (pp. 3-14). Washington, DC Routledge.

Sachs, J. (2001). Teacher professional identity: Competing discourses, competing outcomes. Journal of Education Policy, 16(2), 149-161. doi:10.1080/02680930116819

Samrajya, L. D. (2008). Intuition and insight for professional development: Reflective practice using teaching diaries. Language in India, 8(10), 1-6.

Savenye, C. W., \& Robinson, S. R. (2005). Using qualitative research methods in higher education. Journal of Computing in Higher Education, 16(2), 65-95.
Sixel, D. M. (2013). Teacher perceptions of professional development required by the Wisconsin Quality Educator Initiative, PI 34. Unpublished PhD. University of Wisconsin, Milwaukee. USA.

Skinner, B., Leavey, G., \& Rothi, D. (2019). Managerialism and teacher professional identity: Impact on well-being among teachers in the UK. Educational Review. Retrieved from https://tandfonline.com/doi/full/10.1080/00131911.2018.1556205? scroll=top\&needAccess=true

SLQF. (2015). Sri Lanka Qualification Framework. Retrieved from https://www.ugc.ac.lk/en/all-notices/1156-sri-lanka-qualificationsframework.html

Tan, A. L., Chang, C. H., \& Teng, P. (2015). Tensions and dilemmas in teacher professional development. Procedia: Social and Behavioral Sciences, 174, 1583-1591. doi:10.1016/j.sbspro.2015.01.808

Tuckett, A. G. (2005). Applying thematic analysis theory to practice: A researcher's experience. Contemporary Nurse, 19(1-2), 75-87.

Tuinamuana, K. (2011). Teacher professional standards, accountability and ideology: Alternative discourses. Australian Journal of Teacher Education, 36(12), 72-82.

Villegas-Reimers, E. (2003). Teacher professional development: An international review of the literature. Paris: International Institute for Educational Planning.

Visser, R. D., Evering, L. C., \& Barrett, D. E. (2014). Twitter for teachers: The implications of twitter as a self-directed professional development tool for K-12 teachers. Journal of Research on Technology in Education, 46(4), 396-413. doi:10.1080/15391523.2014.925694

Whitty, G. (2000). Teacher professionalism in new times. Journal of InService Education, 26(2), 281-295. doi:10.1080/13674580000200121

World Bank. (2009). The towers of learning: Performance, peril and promise of higher education in Sri Lanka. Retrieved from http://siteresources.worldbank.org/SOUTHASIAEXT/Resources/Publications/TOLreportfinal.pdf

Wright, A. C. (2012). A literature review on the determinants of teacher performance. Econ 250A. Retrieved from https://pdfs.semanticscholar.org/0c9e/c5237051eecf5b1e6fbe6883f3026a270202.pdf? _ga=2.112198657.422613754.1567246388-108917067.1567246388

Yukhymenko, M. A., Brown, S. W., Lawless, K. A., Brodowinska, K., \& Mullin, G. (2014). Thematic Analysis of teacher instructional practices and student responses in middle school classrooms with problembased learning environment. Global Education Review, 1(3), 93-110.

Zacharias, N. T. (2012). Qualitative research methods for second language education: A course book. Newcastle: Cambridge Scholars.

Zadrozny, J., Mcclure, C., Lee, J., \& Jo, I. (2016). Designs, techniques, and reporting strategies in Geography education: A review of research methods. International Geographical Education, 6(3), 216-233. 